\title{
Illegal Logging Criminal Investigation Process
}

\section{Dwi Agus Istiyono*)}

*) Student of Master of Law, Faculty of Law, Universitas Islam Sultan Agung (UNISSULA) Semarang, E-mail: dwiagusistiyono@gmail.com

\begin{abstract}
.
This study aims to determine the investigation process of illegal logging in the Rembang Police jurisdiction and to find out the obstacles and the resolution of the handling of these obstacles. Illegal logging is basically an activity that begins with logging the forest to get wood, transportation, to the sale of wood which is not in accordance with the rules or is illegal because it does not have an official permit from the competent authority. The approach method used is juridical empirical, descriptive analytical research specifications. The data used are secondary data. Data collection methods are library research and field studies. The data analysis method uses qualitative analysis. As a tool of analysis, law enforcement theory, legal certainty theory and structural functional theory are used. The results showed that the investigation process for illegal logging in the Rembang Police jurisdiction was carried out based on KUHAP and Perkap Polri No. 16 of 2019. The basis for the investigation was a report from Perhutani that had secured the perpetrators and evidence. Then a Police Report is prepared, which is then carried out to carry out an investigation. Obstacles in the enforcement of criminal law on illegal logging in the Rembang Police jurisdiction are obstacles from the law, the return of case files from the public prosecutor, requests for old expert witnesses and lack of legal awareness from the public. Resolutions in dealing with obstacles to criminal law enforcement against illegal logging crimes in the Rembang Police jurisdiction are completing the investigation process in accordance with procedures, completing the case files according to the instructions of the public prosecutor, waiting for expert witnesses to be present or conducting examinations at the location of expert witnesses, and coordinating with Perhutani and Bhabinkamtimas for socialization to the community.
\end{abstract}

Keywords: Investigation; Criminal; Illegal Logging.

\section{Introduction}

Illegal logging or forest logging, known as illegal logging, is clearly a crime or a criminal act. This is as stated by Baharuddin Lopa that one of the main causes of the emergence of crime in society is the increasing and varied human needs, but his income is not able to keep up with the increasing and varied needs of his needs. So, in short, it is due to socioeconomic factors and environmental factors. ${ }^{1}$

Illegal logging is regulated in Act No. 18 of 2013 concerning Prevention and Eradication of Forest Destruction. The definition of forest destruction as stipulated in Article 1 point 3 of Act No. 18 of 2013 is: "The process, method or act of destroying forests through illegal logging activities, use of forest areas without permits or use of permits that are contrary to the intent and purpose of granting permits in forest areas that have been designated, those that have been designated,

\footnotetext{
${ }^{1}$ Lopa, Baharuddin: (2001). Kejahatan Korupsi \& Penegakan Hukum, First Edition. Jakarta: Kompas.p.15.
} 
or that are being processed by the government, "while the definition of illegal logging according to the provisions of Article 1 number 43 of Act No. 18 of 2013 is:" All activities of the use of timber forest products illegally in an organized manner"

Considering that the consequences of illegal logging do not only affect forest areas, but also human life, these crimes must be tackled and eradicated and provide a deterrent effect on the perpetrators through law enforcement. Law enforcement is a process of activities or activities, one of which is carried out by law enforcers (POLRI/PPNS investigators, prosecutors and judges). To produce good law enforcement, the process of each stage in law enforcement must be carried out properly. ${ }^{2}$

The use of legal remedies in law enforcement aims to achieve public welfare in general, so that law enforcement policies are included in the field of social policy, namely all rational efforts to achieve community welfare. ${ }^{3}$

The police is a law enforcement institution that is the spearhead or front guard for the success of criminal law enforcement efforts, which has a difficult task of finding the truth by gathering evidence of criminal acts, by carrying out investigations and investigations. This is in line with the provisions of Article 13 of Act No. 2 of 2002 concerning the State Police of the Republic of Indonesia which states that one of the main tasks of the Indonesian National Police is to enforce the law. 4

In investigations, the emphasis is placed on the act of "seeking and gathering evidence" so that the criminal act found can be clarified and in order to find and determine the perpetrator. ${ }^{5}$

The police, in handling a case until the determination of a suspect, is carried out in accordance with the applicable legal corridors. The police take a series of actions to determine an event that is suspected of being a criminal act (investigation), which is then followed by finding and gathering evidence to make clear the criminal act that occurred (investigation). The police must obtain strong evidence to bring the suspect to trial, while maintaining the presumption of innocence.

\section{Research Methods}

The approach method used in this research is the approach method used is juridical empirical, descriptive analytical research specifications. The data used are

\footnotetext{
2Wahyuningsih, Sri Endah \& Rismanto. (2015). Kebijakan Penegakan Hukum Pidana terhadap Penanggulangan Money Laundering dalam Rangka Pembaharuan Hukum Pidana di Indonesia. Jurnal Pembaharuan Hukum, Volume II No. 1 January - April 2015.p. 47.

${ }^{3}$ Danujaya, I Dewa Putu Gede Anom \& Sri Endah Wahyungsih. (2019). Legal Policy On The Existence Of Criminal Law Of Illegal Foreign Labor In Indonesia, Jurnal Daulat Hukum, Volume 2 Issue 2, June.p. 116.

${ }^{4}$ Gita, Dany Andhika Karya, Amin Purnawan \& Djauhari. (2018). Kewenangan Kepolisian Dalam Menangani Tindak Pidana Pertambangan (Ilegal Mining) Menurut Undang-Undang Nomor 4 Tahun 2009 (Studi di Kepolisian Negara Indonesia), Jurnal Daulat Hukum, Volume 1 No. 1 Marchp. 25.

${ }^{5}$ Harahap, M. Yahya. (2003). Pembahasan Permasalahan \& Penerapan KUHAP, Penyidikan \& Penuntutan. Jakarta: Sinar Grafika,.p.109.
} 
secondary data. Data collection methods are library research and field studies. The data analysis method uses qualitative analysis.

\section{Result and Discussion}

\subsection{The Process of Investigating of Illegal Logging Crime in the Legal Area of the Rembang Police}

The condition of the open forest area makes access in and out of the forest very easy. This triggers a crime, one of which is illegal logging, which can harm Perhutani. In addition, illegal logging/illegal logging can also result in damage which results in disruption of the sustainability of the ecosystem, the occurrence of floods, erosion/landslides, the dysfunction of forests as a buffer for the natural balance as well. ${ }^{6}$

The results of research at the Rembang Police show that the number of forestry crimes, especially illegal logging, is quite high. This is as stated by IPTU Al Sutisna who stated that in the jurisdiction of the Rembang Police, every year they must handle illegal logging crimes. The data available at the Rembang Police show that in 2017 there were 10 illegal logging cases handled, in 2018 there were 11 cases, and in 2019 there were 6 cases. All these cases have been processed until P21. ${ }^{7}$

Investigation procedures for illegal logging crimes at the Rembang Police are carried out in accordance with the provisions of KUHAP and Perkap Polri Number 16 of 2019 concerning Criminal Investigation. Meanwhile, the material law used in illegal logging is Act No. 18 of 2013 concerning the Prevention and Eradication of Forest Destruction. All illegal logging cases handled by the Rembang Police are based on reports from Perhutani, which are usually on patrol and arresting suspects. ${ }^{8}$

The process of investigating illegal logging in the jurisdiction of the Rembang Police is carried out based on the provisions of the Criminal Procedure Code and the National Police Perkap No. coercion, examination, determination of suspects, filing, submission of case files, submission of suspects and evidence, termination of investigations.

The investigation process of illegal logging in the Blora Police jurisdiction is in accordance with the theory of law enforcement as stated by Soerjono Soekanto that the essence and meaning of law enforcement lies in the activity of harmonizing the relationship of values that are outlined in solid and embodied principles and attitudes. Act as a series of final stage value descriptions, to create, maintain, and maintain a peaceful social life. ${ }^{9}$ The main problem of law enforcement lies in the factors that may influence it, namely the legal factors

\footnotetext{
${ }^{6}$ Sodik, Anwar. (2015). Peran Polri Dalam Pemberantasan Perusakan Hutan, Jurnal Pembaharuan Hukum, Volume II No. 3 September-December, p. 422.

${ }^{7}$ Interview with Iptu Al Sutisna, Rembang Police Investigator, March 12, 2020

8 Ibid.

${ }^{9}$ Soekanto, Soerjono. (2016). Faktor-Faktor yang Mempengaruhi Penegakan Hukum, Edisi Pertama, Print-14. Jakarta: Raja Grafindo Persada. p. 5.
} 
themselves (laws), law enforcement factors, facilities or facilities factors, community factors and cultural factors. ${ }^{10}$

Law enforcement against illegal logging in the Rembang Police is influenced by legal factors. In this case, the laws that support law enforcement are Article 12 letters (b) and (c) Act No. 18 of 2013 concerning the Prevention and Eradication of Forest Destruction which states that everyone is prohibited from cutting trees in forest areas without having a license that is issued by an authorized official and illegally felling trees in forest areas. Law enforcement factors also influence law enforcement, in this case the Rembang Police investigator is carrying out an investigation into illegal logging crimes. The facility or facility factors referred to here are the availability of facilities and infrastructure in the process of investigating illegal logging crimes, such as the availability of an adequate budget, sufficient number of investigators, and adequate facilities. Judging from the community factor, it can be said that law enforcement against illegal logging has not been fully supported by the community. In terms of cultural factors, the investigation process carried out by the Rembang Police investigator is a manifestation of the legal cultural values system that applies based on existing laws and regulations.

The process of investigating the illegal logging crime at the Rembang Police is in accordance with the theory of legal certainty. According to Hans Kalsen, laws containing rules serve as guidelines for individuals behaving in society. In its implementation, this regulation creates legal certainty. ${ }^{11}$

The implementation of investigations into illegal logging crimes at the Rembang Police is based on statutory regulations, namely KUHAP and Perkap Polri Number 16 of 2019 concerning Crime Investigation as formal criminal law which regulates the proceedings in investigation. The material legal basis for ensnaring suspects is Article 12 letters b and c in conjunction with Article 28 of Act No. 18 of 2013 concerning Prevention and Eradication of Forest Destruction. Thus the investigation process of illegal logging in the Rembang Police jurisdiction has fulfilled the principle of legal certainty.

Viewed from Emile Durkheim's structural functional theory, emphasizes order and ignores conflicts and changes in society. The basic assumption is that every structure in a social system is functional to others, otherwise if it is not functional then that structure will not exist or disappear by itself. ${ }^{12}$ The process of investigating illegal logging crimes places more emphasis on existing laws and regulations.

\footnotetext{
10Ibid. p. 8

11Kelsen, Hans. (2011). General Theory of Law and State, translated by Rasisul Muttaqien. Bandung: Nusa Media,.p. 7

12 Anto, Rusdi. (2020). Teori-teori Sosiologi hukum Fungsional Struktural, https://www.researchgate.net, accessed on 4 April 2020)
} 


\subsection{Obstacles in Enforcement of Criminal Law on Illegal Logging in the Legal Area of the Rembang Police}

Investigators' efforts to carry out investigations into illegal logging crimes in the jurisdiction of the Rembang Police have experienced several obstacles, namely: ${ }^{13}$

\subsubsection{Legal factors}

The current formulation of the illegal logging crime still categorizes an act of forest destruction based on whether or not a permit is present, legal or illegal, an act of a person or legal entity. The law seems to construct the illegal logging issue as a legal or illegal issue, not on the impact that the forest has been completely damaged, so that the benchmark in its application is whether a business or activity carried out by that person has a permit or not. . This can be interpreted, that if a person has a permit then he does not commit the crime of illegal logging, on the other hand, if he does not have a permit, he has committed an illegal logging crime.

\subsubsection{Factors of law enforcement officers, namely the return of case files from the public prosecutor and the difficulty of bringing in expert witnesses}

The investigation process ends with the submission of the case files to the public prosecutor. This is as stated in Article 28 of Perkap Polri Number 16 of 2019 concerning Criminal Investigation which states that the submission of case files to the Public Prosecutor is carried out after filing in the investigation process is complete. The reality in the field shows that the investigation case files submitted by investigators to the general public are not immediately accepted. The public prosecutor will check the case file. If the public prosecutor feels that there is not enough material, the file will be returned to the investigator accompanied by instructions. Sometimes the return of case files by the public prosecutor to the investigator is not only once, but can be many times so that it can delay the process of completing the investigation.

\subsubsection{Community factors, namely the lack of community legal awareness}

Legal awareness of the community, especially those living around forest areas, is still low. There are still many people who for various reasons cut wood from forest areas belonging to Perhutani without the permission of local officials. The purpose of the community to cut teak trees in forest areas belonging to Perhutani is usually for their own personal needs and not for sale. The community thinks that taking wood in the teak forest area belonging to Perhutani is not an act against the law, because the forest is in their area. Communities commit violations of the law by cutting trees illegally (illegally) influenced by the fact that other community members also do the same thing. Other than that, triggered by public dissatisfaction with the central government policies in the past in the centralized management of forest resources. This has resulted in a sense of public

13 Interview with Iptu Al Sutisna. Loc.Cit. 
dissatisfaction and resentment which has resulted in the community's distrust of current government forestry policies. ${ }^{14}$

\subsection{Resolutions in Handling Barriers to Enforcement of Criminal Law against Illegal Logging in the Legal Area of the Rembang Police}

The efforts made by investigators to overcome obstacles in criminal law enforcement against illegal logging crimes in the Porlre Rembang jurisdiction are as follows:

- To overcome obstacles from legal factors, investigators complete the investigation process in a professional manner based on Act No. 18 of 2013 concerning the Prevention and Eradication of Forest Destruction.

- To overcome obstacles from the factor of law enforcement officials, investigators coordinate with the prosecutor for an extension of detention and Perhutani for an application for expert witnesses, namely the investigator submits a request for an extension of detention for 40 days.

- To overcome obstacles from community factors, the Rembang Police coordinated with Perutani and optimized the role of Bhabinkantibmas so that socialization was carried out to the community regarding illegal logging and its legal consequences. In addition, the Rembang Police have also optimized the role of Babinkamtibmas which is the function of the police whose existence is closest to the community.

\section{Conclusion}

The process of investigating illegal logging in the jurisdiction of the Rembang Police is carried out based on the Criminal Procedure Code and Perkap Polri Number 16 of 2019. Obstacles in criminal law enforcement on illegal logging in the jurisdiction of the Rembang Police are obstacles from the law, returning case files from the public prosecutor, requests for expert witnesses that are old and lack of legal awareness from the public. The solution to overcoming these obstacles is to carry out investigations based on Act No. 18 of 2013, coordinate with related parties, namely the prosecutor's office and Perhutani, coordinate with Perhutani and Bhabinkamtimas for socialization to the community.

\section{References}

Journal:

[1] Danujaya, I Dewa Putu Gede Anom \& Sri Endah Wahyungsih. (2019). Legal Policy On The Existence Of Criminal Law Of Illegal Foreign Labor In Indonesia, Jurnal Daulat Hukum, Volume 2 Issue 2, June

[2] Gita, Dany Andhika Karya, Amin Purnawan \& Djauhari. (2018). Kewenangan Kepolisian Dalam Menangani Tindak Pidana Pertambangan (Ilegal Mining)

\footnotetext{
${ }^{14}$ Sukardi. (2005). Illegal Logging dalam Perspektif Politik Hukum Pidana (Kasus papua), Yogyakarta: Universitas Atmajaya.p. 89.
} 
Menurut Undang-Undang Nomor 4 Tahun 2009 (Studi di Kepolisian Negara Indonesia), Jurnal Daulat Hukum, Volume 1 No. 1 March

[3] Sodik, Anwar. (2015). Peran Polri Dalam Pemberantasan Perusakan Hutan, Jurnal Pembaharuan Hukum, Volume II No. 3 September-December

[4] Wahyuningsih, Sri Endah \& Rismanto. (2015). Kebijakan Penegakan Hukum Pidana terhadap Penanggulangan Money Laundering dalam Rangka Pembaharuan Hukum Pidana di Indonesia. Jurnal Pembaharuan Hukum, Volume II No. 1 January - April 2015

Books:

[1] Harahap, M. Yahya. (2003). Pembahasan Permasalahan \& Penerapan KUHAP, Penyidikan \& Penuntutan. Jakarta: Sinar Grafika

[2] Kelsen, Hans. (2011). General Theory of Law and State, translated by Rasisul Muttaqien. Bandung: Nusa Media

[3] Lopa, Baharuddin: (2001). Kejahatan Korupsi \& Penegakan Hukum, First Edition. Jakarta: Kompas

[4] Soekanto, Soerjono. (2016). Faktor-Faktor yang Mempengaruhi Penegakan Hukum, Edisi Pertama, Print-14. Jakarta: Raja Grafindo Persada

[5] Sukardi. (2005). Illegal Logging dalam Perspektif Politik Hukum Pidana (Kasus papua), Yogyakarta: Universitas Atmajaya

\section{Regulations:}

[1] Act No. 2 of 2002 concerning the Indonesian National Police

[2] Act No. 22 of 2009 concerning Road Traffic and Transportation

[3] Act No. 25 of 2009 concerning Public Services

[4] Chief of Police Regulation Number 9 of 2012 concerning Driving License

Internet:

Anto, Rusdi. (2020). Teori-teori Sosiologi hukum Fungsional Struktural, https://www.researchgate.net, accessed on 4 April 2020)

Interview:

Interview with Iptu Al Sutisna, Rembang Police Investigator, March 12, 2020 